\title{
A BIOGRAPHY: AN INTELLECTUAL OF MODERN TURKEY, KURTHAN FISEK AND SPORTS MANAGEMENT
}

\author{
Onur Hayırıı ${ }^{1 *}$, Dilek İsler ${ }^{2}$ \\ ${ }^{1}$ Mr., TURKEY, ohayirli@yahoo.com \\ ${ }^{2}$ Ms., TURKEY, dileksler@yahoo.com \\ ${ }^{*}$ Corresponding author
}

\begin{abstract}
This is a biographical work. This work is composed of three parts. In the first part, all the principles and philosophical thoughts that Turkey and her independence is based on. Secondly, Kurthan Fisek, who was grown up in an atmosphere when Republic Period and enlightenment brought with it reached its peak in 1950 s and 1960s, is studied in terms of his family, the era and its political and social events, of his educational background and academic life, his field of interests, his major works and books. As the third part, his most important book 'Sports Management' is presented and introduced. This book composed of four parts and additions and discussing sports in a universal aspect is still a reference book in sports circles. The book is also quite universal.

Kurthan Fisek (1942-2012) was one of the famous people in Ankara University, Faculty of Political Science between 1960s and 1970s. He has left important mark on recent history, academic and intellectual life of Turkey. He was a sportsman, academician, translator, journalist, politician, bureaucrat and manager. He witnessed coups staged on $27^{\text {th }}$ May, 1960 and $12^{\text {th }}$ March, 1980. He was judged and tortured in that era. He was a student of Suleyman DEMIREL, Turgut OZAL, Necmettin ERBAKAN and Erdal Inonu who were beginning to be important in political circles and he was the teacher of Abdullah OCALAN, Mesut YILMAZ, Mehmet AGAR and Abdullatif SENER. The founder of PKK Abdullah OCALAN who was a student in Ankara University, Faculty of Political Science in 1960s got zero grade because he did not participate in Kurthan Fisek's exam.

He loved and admired Ankara deeply. He was a member of a Macedonian-originated family who immigrated to Ankara approximately 100 years ago during Turkish War of Independence. His grandfather Hayrullah FiSEK, who was one of the leading commanders of War of Independence, was a classmate of Mustafa Kemal ATATURK and İsmet INONU in Salonika Military Junior High School. His father Nusret FiSEK, who was once an undersecretary of Ministry of Health and a chairman of Turkish Medical Association (TBB), was one of the leaders of preventive medicine in Turkey.

Kurthan FiSEK has two special field of interest: Politics and sports. He was active and took part in socialist-rooted Workers' Party of Turkey (TiP) which for the first time could be a part of the parliament by gaining 15 representatives in general elections of Turkey in 1965. He also took part in Science Council of the party. He was in national team of Turkey in the field of High Jump when he was young. In 1979, he wrote the book 'Sports Management' which is a good reference book. He not only theorized the field of Sports Management but he also presided in Ankara Sports Academy and Turkish Athletic Federation between 1978 and 1979.
\end{abstract}

Keywords: Biography, Kurtan Fisek, Sports Managements, Turkey 


\section{MODERN TURKEY}

No doubt that the history of modern Turkey did not start with the year 1876 when the first constitution was issued by Ottomans because Sultan Abdul Hamit II prevented the assembly from convening and the prevented the constitution from being put into practice from 1878 onwards and also he created an oppressive atmosphere all around the nation for 30 years. This oppressive era ended in 1908 when the assembly was formed again. Intellectuals some of whom were educated abroad and were called as Young Turks played a great role in ending this era. The secret society which was called as The Committee of Union and Progress (Ittihat ve Terakki Cemiyeti) became gradually strong by turning into a party and was effective in governing the country between the years 1908-1918. The Committee of Union and Progress insisted that constitutional era should be revived, the assembly should be convened and all the rights and freedoms of individuals should be strictly protected. The era lasted from the year 1908 when the constitution was put into practice again to the year 1918 when Istanbul was conquered and the assembly was terminated. The era is called as the Second Constitutional Era that had a constitution and an assembly.

A lot of political and social changes took place in the Second Constitutional Era. As a result of the constitutional amendments of 1909, the governing structure of Ottoman Empire changed but stylistically, it became parliamentary and all these paved the way for a more libertarian government. All the principles of parliamentary government and all individual rights and freedoms were adopted. The principles requiring that 'government is responsible to the assembly' and 'the government that cannot win a vote of confidence should withdraw' were adopted and these were the basic elements of the separation of powers. The censorship of media was ended, modern democracy started and also national culture and national economy policy were improved. Equality, freedom, justice and brotherhood spread all over the nation. Individual freedoms, law and women rights were reformed. For instance, secondary education and higher education institutions were opened for girls. Women were given the right that they would be the only wife of their husbands. (Ucbas, 2007, p. 49)

In the Second Constitutional Era, the nation and government started to change gradually into constitutional monarchy and into parliamentary governing rather than absolute monarchy and into the national state rather than multinational empire. There appeared awareness in public who started to deal with politics in a great extent. Such terms as 'citizen' and 'nation' instead of tebaa (slave) showed up. This awareness and consciousness were effective in the success of 'National Struggle' that continued between 1918 and 1922, the same years with the War of Independence and also effective to found a new Independent Turkish State. (Ucbas, 2007, p. 50)

While Ottoman Empire was no longer an independent government with the Treaty of Sevres signed on August 10th, 1920 and its lands were being conquered, some oppositional organizations called as Kuva-yi Milliye (Nationalist Forces) were founded. The Grand National Assembly of Turkey founded in April 23rd, 1923 made it easy to support national struggle, to gain independence, to guarantee the freedom of people and nation and to create a new nation. In the constitution prepared in 1921, it was said that 'Sovereignty unconditionally belongs to the nation' and the source of sovereignty changed from absolute power to the citizens. For the first time, the fact that sovereignty belongs to not one person but to the whole nation became a rule of law. On April 29th, 1923, it was accepted that the regime of the government was 'Republic'. As a result of all these developments that had happened abroad in the 18th century with American and French Declarations of Independence, the foundations of the Modern Turkey seemed to be laid.

The founder of Modern Turkey (The Republic of Turkey) Mustafa Kemal (Ataturk) was following the scientific, social and political developments of his age. His thoughts are based on humanism, enlightenment and positivism. Humanism attaches importance to human, enlightenment to mind and reason and Positivism to science. That's why he bases his thoughts on human and human values, mind, reason and science which is the product of human mind.

Mustafa Kemal was trying to create a modern society and government who would think and create in a modern way. He was inspired and influenced by the social and political developments of his age. All the improvements brought by industrialization of the 18th Century in Europe and 1789 French Revolution shook the economic and political atmospheres of the societies. Feudal system that was based on land ownership started to collapse, monarchies that was based on an absolute power started to disappear and multinational empires fell apart. After all these, some new government structures showed up such as democratic state which guaranteed individual rights and freedoms, national state which is based on freedom of the nation, state of law which adopts the supremacy of law and equality and secular state which is respectful to the beliefs. The foundations of the Republic of Turkey which Mustafa Kemal called as 'My biggest work of art' are based on these principles. (Ucbas, 2007, p. 83)

\section{SECTION KURTHAN FISEK, HIS FAMILY ROOTS AND LIFE}

As one of the very influential second generation intellectuals of Modern Turkey, he was born in Ankara in 
1942 in a family who immigrated from Macedonia, he always lived in Ankara, he passed away in April 17th, 2012 and was buried in Ankara.

His family roots dates back to Mustafa Ruhi Efendi who was a Macedonian Naqshbandi sheikh. The Sheikh used to produce fireworks and sell them to gangs. Therefore, the family surname is 'FiSEK' (meaning firework in Turkish). His grandfather Hayrullah Pasha was one of the most important commanders of Turkish War of Independence and he was a classmate of Mustafa Kemal and Ismet Inonu in Salonika Military Junior High School. His father Nusret FiSEK was the leader and founder of preventive medicine, very successful in founding the field of 'public health', planned and succeeded in socialization in medicine, started the population planning and one of the founders of Hacettepe University. His maternal grandfather Ali Taha Bey was rooted in Macedonia, was a judge in Izmir and came to Ankara after the Occupation of Smyrna. (Cakır, 2012)

So, Kurthan Fisek had such a successful and talented family. He was hardworking, smart and creative just like his other family members. (Kongar, 2015)

Kurthan FiSEK's marriage with ballerina Neyran FISEK lasted 42 years till his death. Kurthan Fisek told about their marriage that lasted nearly half a century that 'Neyran knows nothing about politics and I know nothing about ballet. Thus, there were lots of things to ask and learn from each other.' (Cakır, 2012)

\subsection{His Education, Academic Years, Journalism and Chairmanship}

He started his education in Boston Martin Millmore. Then he enrolled in Ankara Mimar Sinan for his secondary education and completed it in Turkish Education Association in Ankara. In 1960, he enrolled in Middle East Technical University (METU) in the department of Chemistry. However, he graduated from Political Science and Public Administration department of the Faculty of Economics and Administrative Sciences. He became a research assistant in Ankara University in the department of Public Administration of the Faculty of Political Science in 1965. He commenced and became a doctor in 1969 with his thesis named 'The Critical History of Strikes against Government', became an associate professor in 1975 with his work 'Participation in Governing', became a professor in 1980 with his book 'Sports Management'. (AU SBF Resmi Sitesi)

When Kurthan FISEK started higher education in 1960, he also worked as a journalist. He worked as a reporter in the newspapers like 'Gun' and 'Oncu' between the years 1960-1966. He was the editor in chief in Turkish Daily News for four years. Between 1980 and 1983, he was the president of Ankara Sports Academy and Athletic Federation. He was deputy dean of Faculty of Political Science in Ankara University in 19801983. Military government discharged him in 1983. However, he went back to his position of deputy dean in 1990 with adjudication. The same year, he resigned and started to be a journalist again. He was a publication and management consultant in such magazines as Nokta, Aktuel, Ekonomist, Erkekce, Playmen and Penthouse. He was a columnist in the newspapers Sabah and Hurriyet. He went back to his position in the academy in 1999. (Vikipedia, 2015)

His foreign languages were French, English and German. He was a sportsman, academic, translator, journalist, columnist, consultant, politician and chairman.

They say for writers that his writing is quite powerful. Yes, his writing was powerful. He drew his strength from his analytical mind, fund of knowledge, most important of all from his creativity. (Bildirici, 2012)

\subsection{Fields of Interest}

Deniz Bilge CAKIR who did the last interview with Kurthan FiSEK on April $7^{\text {th }}, 2012$ expressed that: 'Talking with Kurthan Fisek feels as if we delved into deep seas. The people who know Kurthan Fisek will enjoy this interview, the others that do not know will certainly love him.' (Cakır, D. 2012)

Kurthan Fisek has two fields of interest. One is Sports, the other one is Politics. He became successful in high jump. He came in second of Ankara in table tennis and also second of Ankara in swimming butterfly stroke. His statement about the three football teams of Turkey is quite famous. The statement is as the following: 'Galatasaray is the team of Europeanized aristocracy, Fenerbahce is the team of bourgeoisie, as for Besiktas, it is the team of working class.' (Web Dictionary, 2015) He was an active participant of the Workers' Party of Turkey (TiP) which was inclined to socialism and could become a part of parliament with its 15 representatives in 1965 . He was a member in the Council of Science of this party. He wrote several articles in Emek Magazine. He was a leading figure in founding Federation of Debate Clubs which formed the basis of The Turkish Revolutionary Youth Federation (Turkiye Devrimci Genclik Federasyonu). (Fishek, 2014) He witnessed many important historical and political events between May 27th, 1960 and September 12th, 1980. He was judged when military government was in power. He was tortured and invalided out of the service in the university.

Besides sports and politics, he was interested in anagram which is a type of play played by rearranging the words and he was fond of detective novels. He had 7200 detective novels. He says; 'After Abdul Hamit II, 
I have the biggest detective novel archive.' He claimed that a good detective novel is a good literature. Furthermore, Kurthan Fisek loved Ankara deeply. He was a true lover of Ankara. He has a book named 'Ankara'. Unlike Yahya Kemal who says that the most beautiful side of Ankara is the way returning to Istanbul', Fisek says that the most beautiful side of Istanbul is the way returning from İstanbul. He has some bad habits such as smoking, alcohol and horse race. (Cakır, 2012)

\subsection{A Student of Famous People, a Teacher of Famous People, 'Sıfırcı Hoca' Kurthan Fisek}

Kurthan FISEK was both student and teacher of some of the names that became important in the last 50 years of political life in Turkey. He was the teacher of these people: : Suleyman DEMIREL, Erdal INONU, Necmettin ERBAKAN, Turgut OZAL. Ogrencisi olanlar: Mesut YILMAZ, Murat KARAYALCIN, Hasan Celal GUZEL, Mehmet AGAR, Apdullatif SENER, Apdullah OCALAN, Mahir CAYAN, Huseyin CEVAHIR.

He never made a student fail a course. He never grades his students with 'zero' if they take his class and take the exams. However, Abdullah OCALAN who was a student in the Faculty of Political Science in 1960s and founded PKK later got zero from FiSEK's exam and failed his class. That's why he is known as 'Sifircl Hoca'.

\subsection{His Works}

He wrote thousands of articles in Turkish, German and English and wrote 15 books as an academic, writer and journalist. His major works : the Development of Capitalism in Turkey and Working Class(1969), the Critical Analysis of Strikes against Government (Phd thesis,1969), Socialist Government in 100 Questions (1970), Administration (1975), Participation in the Governing (1977), Sports Management (1980), The History of Sports in Turkey (1985), the Anatomy of Sports (2003), Why We Should Love Football (2006), the First Century of Arm Trade between Turkey and the US 1829-1929 (2007), Ankara (2012).(Vikipedia, 2015)

\section{SPORTS MANAGEMENT}

'Sports Management' is FiSEK's most important work. For the first time, it was published by Ankara University Faculty of Political Science in 1980. It is a 564-page book. Its full name is 'Sports Management in the World and Turkey in terms of the Relations of Government Policies and Social Structure'. The book is composed of four parts and additions that FISEK himself attached much more importance on. Here are the titles of the parts:

Part I: (Introduction) Universality of Sports: History, Definition, Way of Use and Corporate Affairs.

Part II: Sports Management in the World: Management and Application in International and National Scope.

Part III: an Original Example for the Transition from Volunteer based teams to Governmental Management

Part IV: (Conclusion and Analysis) Towards a Democratic Sports Management in National and International Scope

\section{Additions: Guideline of Turkish Sports Organization}

The first part (Introduction) analyses the universality of sports. It gives a short history and gives a broad definition of sports in terms of aesthetics, technique, physics and economics. It is all discussed here that sports has such functions as preparing individuals for military service, socializing people, bringing citizens together and spending free times effectively. It also functions as a medium of peace and propaganda in international relations. Lastly, the tie between sports and government, politics, economy, diplomacy and law is detailed.

The second part consists of applications and theories used worldwide in the field of sports management. In this part, Fisek makes a distinction between physical education and sports. He analyses such approaches as 'Voluntary unity', 'government' and 'paramilitary organization' which is the distorted version of government. Then, he continues to analyze the international sports regulations, national and international sports organization and their relationships with each other and he asks the question whether there are universal principles and organization types by giving examples all around the world.

The third part deals with the past and present of sports management. In this part, he details the three historical stages of the development of sports management in Turkey: The Era of Voluntary Unity (19031936), the era of semi-official organizing (1936-1938), the era of Government (After 1938). (Fisek, 1980, p. 7-8) 'Istanbul Football Association' and 'Istanbul Football League' was founded in 1903 which were the pioneers of the Voluntary Unity and 'Istanbul Friday League' was founded in 1913. Turkish Sports Association (Turkiye İdman Cemiyetleri İttifakı) was founded in 1922 and this event was quite important for the voluntary unity era. (Fisek,1980, p. 515-526) The Semi-official organizing era started with 1936 when the 
name of the organization was changed into 'Turkish Sports Administration' and It was connected to Republican People's Party. The era ended in 1938 when the General Management of physical Training was founded. (Fisek, 1980, p.535) As for the Era of Government, it started in 1938 when the General Management of physical Training was founded. It continued with the foundation of the Ministry of Youth and Sports in 1969. (Fisek, 1980, p.544) In the third part, the history of sports management is analyzed technically and historically. First of all, the structure, techniques, principles and process of each sports organization are presented. Then, the corporate affairs of sports and sports management are analyzed between the years 1903 and 1980.

The fourth part (Conclusion and Analysis) includes a general analysis of Turkey and the world. In this part, some problems of Turkish sports organization are analyzed. Fisek proposes 'a governing structure' for Turkish sports. (Fisek, 1980, p. 544)

The 'Additions' part is a kind of Guideline of Turkish Sports Organization. In this part, all the laws, regulations and legislations of Turkish sports organizations founded after 1903 (the date when Istanbul Football Association was founded) are summarized. For Fisek, The most important feature of this part is that for the first time all the laws and regulations in the field of sports management were gathered, collected, written and published in a single book by protecting their original languages.

Kurthan Fisek's work 'Sports Management' is the most comprehensive work that he discussed sports, its universal characteristics. He passed readers on its history and detailed applications and theories of sports. The work is still a reference book in the field of Sports Management and a marvellous source for the field. People working on sports management should certainly know Kurthan Fisek and his book 'Sports Management'.

\section{REFERENCE LIST}

Ucbas, T. (2007) Demokrasi ve İnsan Hakları, Fil Publishing, İstanbul

Fisek, K. (1980). Spor Yonetimi, Ankara Universitesi SBF Publishing, Ankara

Cakır, D.B. (2012) “Kurtan Fisek'ten Veda Roportajı”, 18 Sept. 2012 , link; http://www.halkinhabercisi.com/abdullah-ocalana-sifir-veren-hoca-kurthan-fisek (20.04.2015,last checked)

Kongar, E. (2015), Kongar E.'s official web page link; www.kongar.org/remzi/020_Kurthan_Fisek.php (20.04.2015)

Bildirici F. (2012). "Kurtan Fisek", 17 Sept. 2012, Bildirici's official web page link; http://www.farukbildirici.com/index.php?Did=512, (20.04.2015)

Fisek.(2014), Fisek Family Web Page link; http://kurthan.fisek.net/ (20.04.2015)

Web Dictionary (2015): Kurtan Fisek Entry Link; http://www.uludagsozluk.com/k/kurthan-fi\%C5\%9Fek/ (20.04.2015)

Vikipedia (2015): Kurtan Fisek Entry Link; http://tr.wikipedia.org/wiki/Kurthan_Fi\%C5\%9Fek (20.04.2015)

Ankara University,(2015) Faculty of Political Sciences Official :

http://yonetimbilimi.politics.ankara.edu.tr/files/2013/07/fisek.pdf (20.04.2015) 